\title{
奥大栄地すべりにおける超大口径鋼管杭の設計と施工
}

Design and Construction of Super Large Diameter Steel Pipe Pile in Okuooe Landslide

国土防災技術株式会社／磯貝尚弘

Japan Conservation Engineers Co., Ltd. / Naohiro ISOGAI

国土防災技術株式会社 /藤田耕二

Japan Conservation Engineers Co., Ltd. /Kouji FUJITA

キーワード：急傾斜, 退行性地すべり, 超大口径, 抑え杭,

Key words : Steep Slope, retrogressive failure slide, Super Large Diameter, the cantilever type Pile

1.はじめに

奥大栄地すべりは, 愛媛県松山市の南西 $20 \mathrm{~km}$ 伊予灘 に面した伊予市双海地域事務所の南東約 $4 \mathrm{~km}$ に位置す る。(図-1)

当地すべり地は，昭和初期の頃から地元民により「石 こけ場」と称され，危険な箇所として認識されていた地 区である。昭和 18 年 7 月 $21 \sim 24$ 日の豪雨により下流「久 保」地区まで大被害を受けた記録があり，この豪雨によ る斜面崩壊を契機として地すべりが発生したと推測され
ている。

当地すべり地は昭和 49 年 8 月 31 日農林省告示 826 号で 8.40haが地すべり防止区域に指定され，愛媛県により 調査・対策工事が実施されていたが，昭和 62 年に再び活 発化した地すべり滑動を機に，抜本的な対策が推進され ることとなった。

その後，平成元年 3 月と平成 2 年 1 月の 2 度の急激な 滑動により，地すべり滑動土塊全体の抜け落ちが予想さ れる危険な状態となっため，排土工・アンカー工・堰是

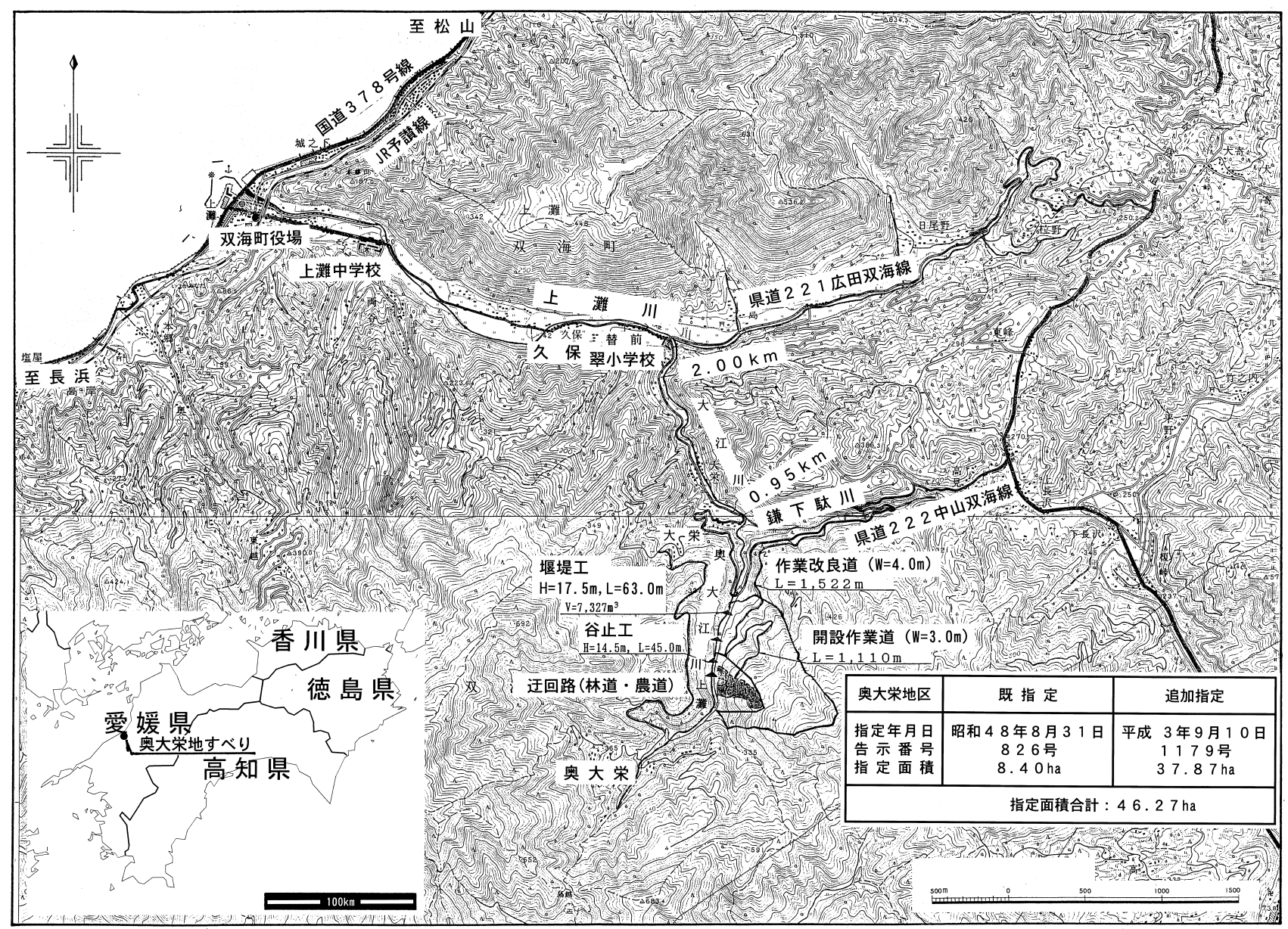

図－1 位置図・周辺地形図（国土地理院発行 2 万 5 千分 1 地形図：上灘・中山及び電子国土地図に加筆） 


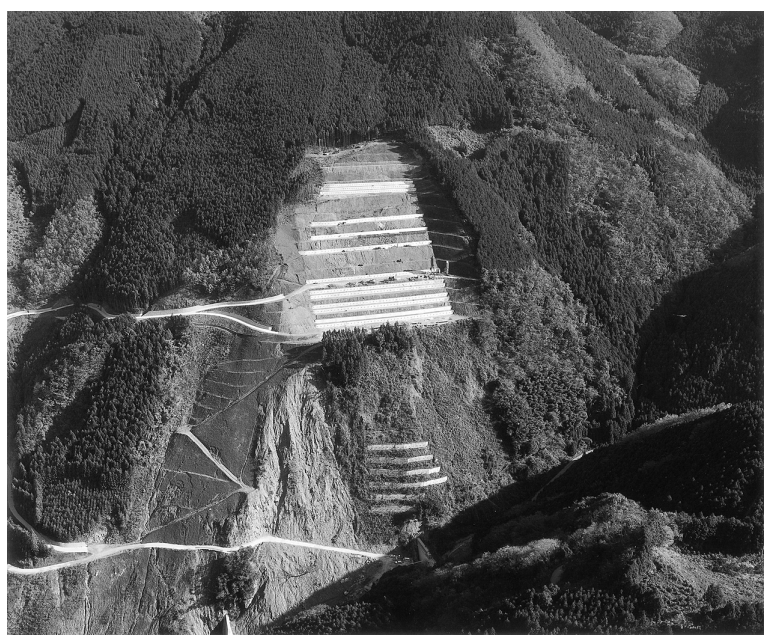

写真- 1 対策工施工中の全景

工を主体とした災害関連緊急対策工事が平成 2 年と 3 年 の 2 回おこなわれ，地すべり・土石流災害が食い止めら れた。

その間, 平成 3 年 9 月 10 日には農林省告示第1179号に よって37.87haが地すべり防止区域に追加指定されてい る。

奥大栄地すべり最大の特徵は急傾斜面に発生した最大 地すべり推力 $45,900 \mathrm{kN} / \mathrm{m}$ の地すべりということである。

ここでは, 地すべりの概要とともに，斜面末端部の地 すべりブロックが抜け落ちた場合に，その影響が斜面上 方のブロックへ及ぶのを防ぐとともに地すべりを抑止す るために施工された超大口径鋼管杭の設計と施工につい て報告する。

\section{2. 地形・地質概要}

奥大栄地すべりは, 愛媛県伊予市双海町をほぼ $\mathrm{E}-\mathrm{W}$ から NE-SW方向に横断する「中央構造線」の南約 $2 \mathrm{~km}$ にあり三波川帯内に位置するため, 南側のENE-WS方 向に走る背斜軸と中央構造線に挟まれた地域内にあって, 全体的に北側に傾斜する変成岩が分布している。

また，安山岩質火成貫入岩体が中央構造線付近に存在 しており，地すべり地対岸側に分布が認められる。

当地すべり地は, 緑色片岩を主体とする結晶片岩と緑 色片岩黒色片岩互層が分布し, 走向傾斜は, N70 9 ${ }^{\circ}$ $\mathrm{E} \cdot 15 \sim 30^{\circ} \mathrm{N}$ あ゙り地すべり斜面に対しては，45～60 北側へ斜交しているが，流れ盤となっている。（図－2）

地すべり地は, 中央構造線に対して直角方向であるS

- N方向に流下する奥大江川の右岸 ·西向き斜面に当り, 凸状，散水斜面形を示し，標高が低くなり奥大江川に近 くなるほど斜面傾斜が急になっている。

地すべりは，標高220～440mに発生しており，亀裂と 斜面傾斜から 3 つ大ブロックに区分される。

・下部ブロック：標高 $220 〜 285 \mathrm{~m}$ ：傾斜約 $43^{\circ}$

・主体ブロック：標高285～395m：傾斜約 $35 \sim 30^{\circ}$

・拡大ブロック：標高395〜 440m：傾斜約 $23^{\circ}$

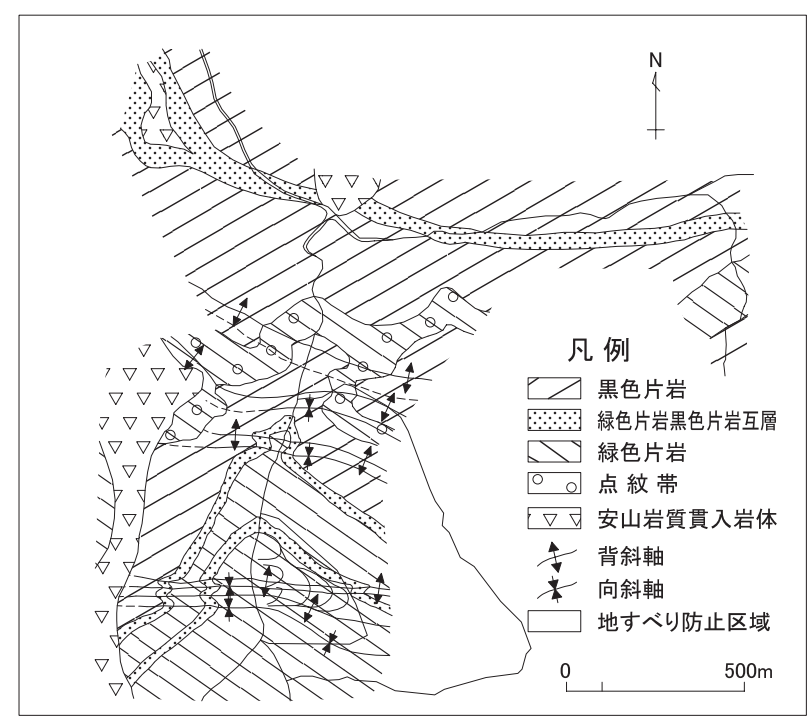

図－２周辺地質図

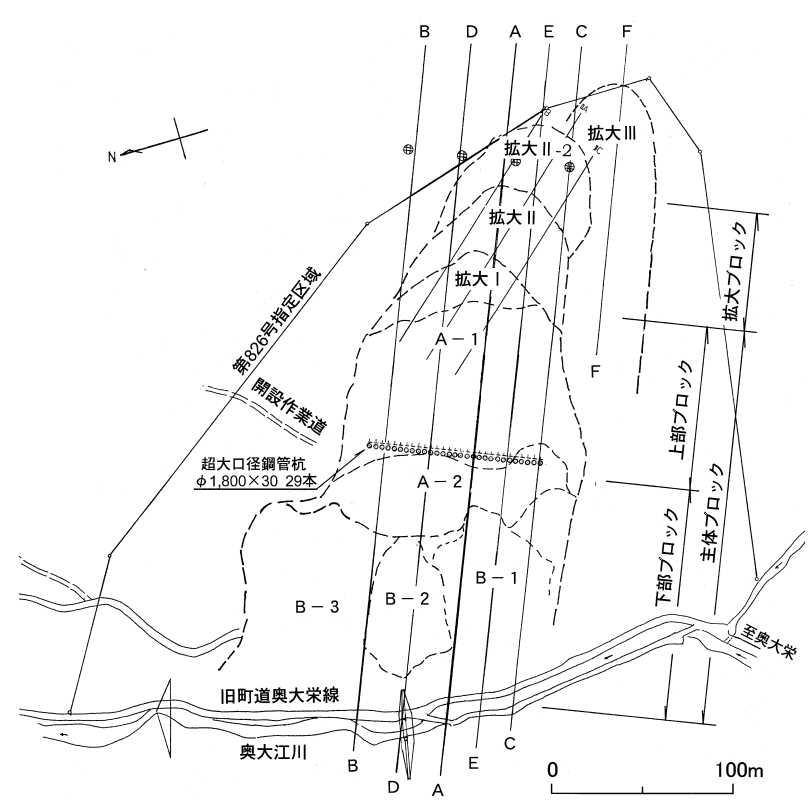

図一３ブロック区分図

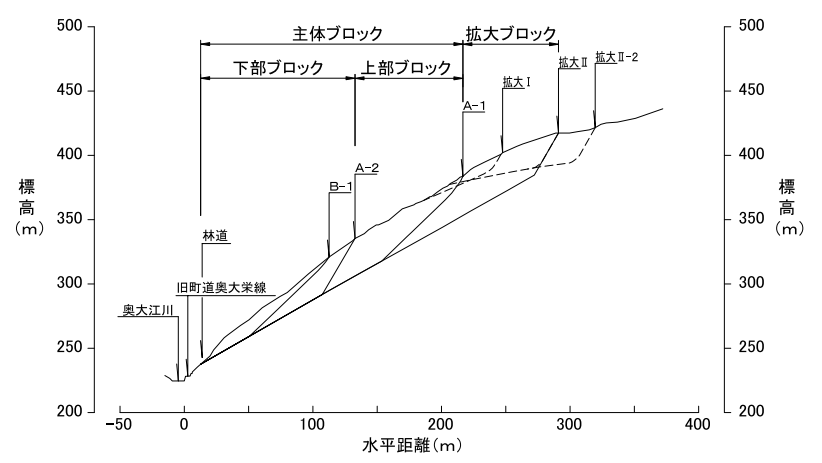

図一 4 A測線断面図

また，すべり面傾斜の緩い退行性地すべりブロックと して, 拡大 I ・拡大 II ・拡大 II - 2 ・拡大 III ブロックが 区分されている。（図-3，4） 


\section{3．地すべりの履歴と対策工法の変遷}

地すべり地の末端・奥大江川の右岸には，地すべり地 より上流の奥大栄集落に通じる唯一の生活道路である旧 町道「奥大栄線」が通っており, 旧町道の交通を常に確 保することが対策工選定の前提条件であった。

地すべり対策工法は地すべり滑動の履歴および旧町道 迂回路の開設に伴い，地下水排除主体の抑制工から抑制 工 (地下水排除工) + 抑止工 (シャフト杭工)，抑制工 (排 土工）+抑止工（アンカー工）へと 2 回の変更を経て現 在に至っている。表- 1 にブロック別移動量の推移と併 せて概略を示す。

\section{4.設計対象ブロックの安定解析と設計条件}

無降雨期においても活動を停止しない地すべりに対す る対策工法の基本方針は，以下の 4 点である。

(1)排土工による安全率のUPと地すべり推力の低減

(2)アンカー受圧版1)背面地盤の地耐力確保

(3)アンカー工による斜面上方からの地すべり抑止

(4)大きな移動量を示す下部ブロックが抜け落ちた場合 に施工済み対策工に影響が及ぶ事を防止する

以上の基本方針の内，(4)の方針に対応するため，下部 ブロックの頭部に杭下流側の地盤反力を期待しない杭打 工を計画した。具体的な工種比較としては工事用作業道

\section{表一 1 地すべり履歴と対策工の変遷}

\begin{tabular}{|c|c|c|c|c|c|}
\hline \multirow{2}{*}{ 区分 } & \multirow{2}{*}{ 年度 } & \multicolumn{3}{|c|}{ 地すべりブロック·移動量:mm/年 } & \multirow{2}{*}{ 対策工 } \\
\hline & & 下部ブロック & 主体ブロック & 上部ブロック & \\
\hline & S48 & & & & 町道落石対策:土留工 \\
\hline \multirow{3}{*}{\begin{tabular}{|c|}
$\mathrm{S} 49 \sim 55$ \\
地すべり対策 \\
着手前
\end{tabular}} & S52 54 & & $30 \sim 42$ & & \\
\hline & \multirow[b]{2}{*}{ S55 } & \multicolumn{4}{|c|}{ 下部ブロック: 地すべり性崩壊発生 } \\
\hline & & $\begin{array}{c}\text { B-1 } \\
1,709\end{array}$ & 310 & & \\
\hline \multirow{4}{*}{\begin{tabular}{|c|} 
S56 57 \\
地すべり対策 \\
第1期
\end{tabular}} & S56 & & 203 & & \multirow{2}{*}{\begin{tabular}{|c} 
崩壊対策:アンカーエ, 杭打エ, \\
ボーリング暗渠エ \\
地すべり対策:トンネル暗渠+ \\
大口径落とし込みボーリング
\end{tabular}} \\
\hline & S57 & & 97 & & \\
\hline & S58 61 & \multicolumn{4}{|c|}{ 地すべリ活動鎮静化 } \\
\hline & $S 62$ & \multicolumn{4}{|c|}{ 地すべり活動活発化:新たなキレツ発生，大口径落とし込みボーリング切断 } \\
\hline \multirow{4}{*}{$\begin{array}{c}\text { S63 H1 } \\
\text { 地すべり対策 } \\
\text { 第2期 } \\
\text { 抑制エ= } \\
\text { 集水井エ } \\
\text { 抑止エ= } \\
\text { シャフト杭エ } \\
\end{array}$} & 63 & $\begin{array}{c}\text { B-1:52.6 } \\
\text { A-2:32.7 } \\
\text { 計 } 85 \\
\end{array}$ & 363 & $\begin{array}{c}\text { 拡大 I } \\
59 \\
\end{array}$ & $\begin{array}{l}\text { 1回目対策工法変更: 集水井効果を } \\
\text { 兼ね備えたシャフト杭工法 } \\
\text { 集水井 } 5 \text { 基 } 70 \mathrm{~m}\end{array}$ \\
\hline & $\mathrm{H} 1 \cdot 3 \& 9$ & \multicolumn{4}{|c|}{ 下部ブロック活動激化:H1·1月=B-1ブロック激化，H1·9月=B-1ブロック激化 } \\
\hline & $\mathrm{H} 1$ & $\begin{array}{l}\text { B-1:1,357 } \\
\text { B-2:7,000 }\end{array}$ & 507 & \begin{tabular}{|c|} 
拡大 I $: 56.4$ \\
拡大 II $: 15.2$ \\
計73
\end{tabular} & \begin{tabular}{|l} 
集水井7基 $110 \mathrm{~m}$ \\
B-2単独対策:杭打工 35 本 $275 \mathrm{~m}$, \\
アンカーエ101本 $5,471 \mathrm{~m}$
\end{tabular} \\
\hline & $\mathrm{H} 2 \cdot 1$ & \multicolumn{4}{|c|}{ 下部ブロックおよび主体ブロック活動激化 } \\
\hline \multirow[t]{2}{*}{$\begin{array}{c}\mathrm{H} 2 \sim 11 \\
\text { 地すべり対策 } \\
\text { 第3期 }\end{array}$} & H2 & \begin{tabular}{c|} 
B-1:5,903 \\
A-2:326 \\
計6,249 \\
B-2:94 \\
\end{tabular} & 792 & \begin{tabular}{|c|} 
拡大 I $: 47.9$ \\
拡大 II $: 7.2$ \\
計 55
\end{tabular} & \begin{tabular}{|l} 
2回目対策エ法変更: 排土エを併用 \\
したアアンーエ \\
·排土エ15万m3 3 (超大口径鋼管杭 \\
施エステップまで)
\end{tabular} \\
\hline & $\mathrm{H} 3 \cdot 7$ & \multicolumn{3}{|c|}{ 拡大 II -2ブロック発生 移動量:657 } & \multirow{7}{*}{  } \\
\hline \multirow{6}{*}{$\begin{array}{c}\text { 抑制エ }= \\
\text { 排土エ } \\
\\
\text { 抑止エ }= \\
\text { アンカーエ+ } \\
\text { 超大口径鋼 } \\
\text { 管杭 }\end{array}$} & H3 & $\begin{array}{c}\text { B-1:582.5 } \\
\text { A-2:241.8 } \\
\text { 計 } 824 \\
\text { B-2:67 } \\
\end{array}$ & 30 & 0 & \\
\hline & H4 & 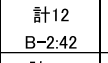 & 変動なし & 変動なし & \\
\hline & H5 & $\begin{array}{l}\text { 計 } 114 \\
\text { B-2:-3 } \\
\end{array}$ & 変動なし & 変動なし & \\
\hline & H6 & B-1:-3 & 変動なし & 変動なし & \\
\hline & $\mathrm{H} 7$ & B-1:-4 & 変動なし & 変動なし & \\
\hline & $\mathrm{H} 8 \sim 11$ & 変動なし & 変動なし & 変動なし & \\
\hline \multirow{3}{*}{\begin{tabular}{|c|} 
H12 現在 \\
地すべり対策 \\
第4期
\end{tabular}} & H9 & 変動なし & 変動なし & 変動なし & \multirow{3}{*}{$\begin{array}{l}\text { 作業道対策:A·B·Cブロ } \\
\text { •アンカカー段 } 98 \text { 本 } \\
\text { 拡大IVブロック対策: } \\
\text { ·集水井工2基 } 56.5 \mathrm{~m}\end{array}$} \\
\hline & $\mathrm{H} 10$ & 変動なし & 変動なし & 変動なし & \\
\hline & H11 & & & 変動なし| & \\
\hline
\end{tabular}

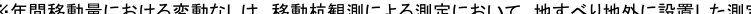
点と同程度の変動量が観測された場合の判定である。
路の開設により施工機械の搬入が可能となった超大口径 鋼管杭とアンカー付きシャフト杭を比較し，経済性扮よ び施工の安全性から超大口径鋼管杭の採用を決定した。

\section{1 安定解析}

超大口径鋼管杭工の設計対象ブロックは，主体ブロッ クの内，下部ブロックの抜け落ちを考慮した上部ブロッ クである。

安定解析は

(1) 地すべり幅が130mと広い

(2) 地すべりブロック内をとおる断面ごとにすべり 面深度・傾斜・地すべり推力が異なる

ことから，

(1) 排土工の形状・効果が測線毎に異なることを考 慮する必要がある

(2) 副測線断面の地すべり推力は一般に主断面の地 すべり推力より小さく，主断面のみによる解 析・設計は過大設計となりやすい

ため，地すべりを三次元的に捉えて経済的な対策工の検 討が可能となるよう，A〜Eの 5 測線を用いLambe \& Whitemanの提案する近似三次元解析法 ${ }^{23}$ よっておこ なっている。また，各断面の二次元安定解析には簡易ヤ

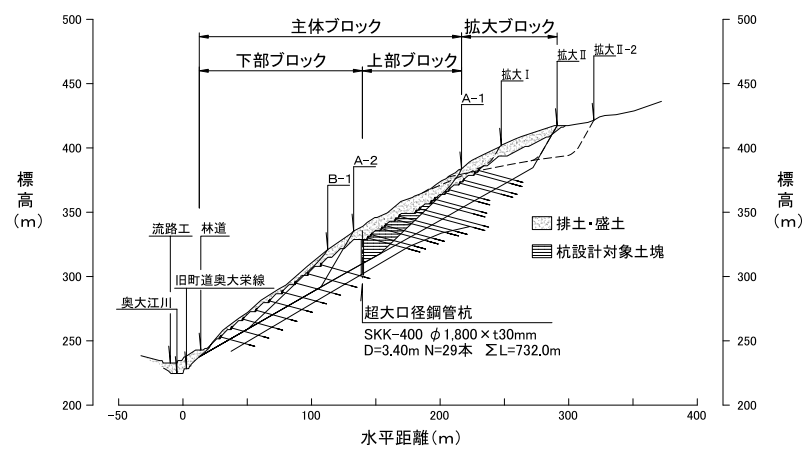

図一 5 A測線対策工断面図

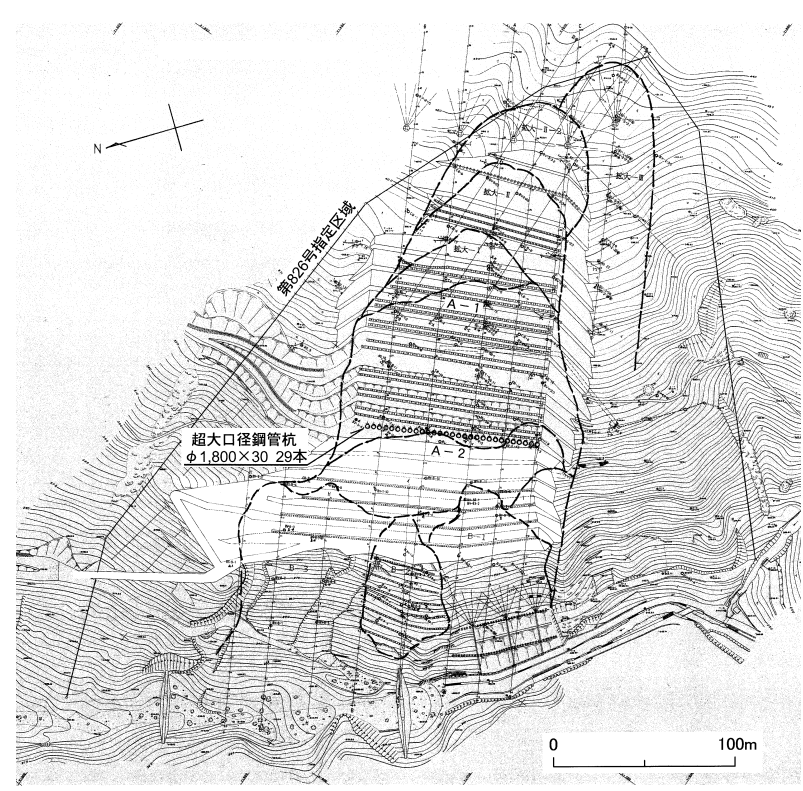

図一 6 対策工平面図 
ンブ法を用いている。安定解析の結果を表 - 2 に示す。

なお，粘着力c'は，地すべりブロックの移動量が $1 \mathrm{~m}$ 以上に達し，側壁亀裂も明暸に連続している事から残留 強度に低下しているとして $\mathrm{c}^{\prime}=0 \mathrm{kN} / \mathrm{m}^{2}$ とした。また， 間隙水圧uは卓越した有圧地下水が無く, 地下水が観測 されるのは一部のボーリング孔に限られ, 無降雨状態で も地すべりの滑動が観測されることから，地下水排除工 による安全率の向上はほとんど期待できない事からu= 0 とした。

\section{2 達成安全率と負担推力}

超大口径鋼管杭工による水平負担荷重は，上部ブロッ クの排土工およびアンカー工 ( 6 段)施工後，下段ブロッ ク抜け落ち状態 $(\mathrm{F} 3=1.05)$ より安全率F $3=1.12$ を 達成するものであり，アンカー工 6 段の効果を除いた場 合の超大口径鋼管杭工による達成安全率はF $3=0.9362$ である。

したがって, 水平負担推力Huは表- 2 上部ブロッ ク：排土状態の各測線の地すべり力 $\Sigma \mathrm{T} よ り$ 杭の水平負 担推力Huを引き, 三次元安全率がF $3=0.8874 \rightarrow 0.9362$ になる值として $482.98 \mathrm{kN} / \mathrm{m}$ を求めた。

\section{3 設計条件}

超大口径鋼管杭工設計の設計条件を示す。

(1)杭下流側の地盤反力を考慮しない片持梁杭 = 抑え杭 として設計する

(2)杭とボーリング孔壁の間の余掘空間はモルタルで充 填する

(3)杭は, せん断破壊に対しても，曲げ破壊に対しても 安全

(4)杭の許容最大たわみ量： $2 \mathrm{~cm}$ 以下

(5)杭と杭の間が中抜けを生じてはならない

表- 2 安定解析結果

\begin{tabular}{|c|c|c|c|c|c|}
\hline 測線 & $B$ & $\mathrm{D}$ & A & $\mathrm{E}$ & $\mathrm{c}$ \\
\hline 間隙水圧 & \multicolumn{5}{|c|}{$\mathrm{U}=0$} \\
\hline 修正係数:fo & 1.0492 & 1.0408 & 1.0368 & 1.033 & 1.0285 \\
\hline 断面積: $\mathrm{A}\left(\mathrm{m}^{2}\right)$ & $2,898.1$ & $3,791.6$ & $3,733.9$ & $3,425.4$ & $3,147.0$ \\
\hline 地すべり抵抗力: $\Sigma S(\mathrm{kN} / \mathrm{m}$ & $33,430.18$ & $42,257.44$ & \begin{tabular}{|l|l|}
$40,957.57$ \\
\end{tabular} & $37,183.87$ & $34,234.33$ \\
\hline 地すべリカ: $\Sigma T(k N / m)$ & $33,036.64$ & \begin{tabular}{|l|l|}
$44,207.79$ \\
\end{tabular} & \begin{tabular}{|l|l|}
$45,888.75$ \\
\end{tabular} & $41,966.58$ & $40,940.21$ \\
\hline 粘着力: $\mathrm{c}^{\prime}\left(\mathrm{kN} / \mathrm{m}^{2}\right)$ & \multicolumn{5}{|c|}{0.000} \\
\hline 内部摩擦角: $\tan \phi^{\prime}$ & \multicolumn{5}{|c|}{$0.596707\left(\phi^{\prime}=30.2480^{\circ}\right)$} \\
\hline 二次元安全率:F2 & 1.0617 & 0.9948 & 0.9254 & 0.9153 & 0.860 \\
\hline 三次元 & \multicolumn{5}{|c|}{0.95} \\
\hline
\end{tabular}

上部ブロック:排土(主体ブロック排土，下部ブロック抜け落ち)

\begin{tabular}{|c|c|c|c|c|c|}
\hline \multirow{2}{*}{ 測線 } & & & & & \\
\hline & $B$ & $\mathrm{D}$ & A & $E$ & $\mathrm{C}$ \\
\hline 間隙水圧 & \multicolumn{5}{|c|}{$\mathrm{U}=0$} \\
\hline 修正係数: fo & 1.0613 & 1.0502 & 1.0208 & 1.0297 & 1.0343 \\
\hline 断面積: $\mathrm{A}\left(\mathrm{m}^{2}\right)$ & 693.8 & 736.7 & 727.4 & 731.6 & 635.5 \\
\hline 地すべり抵抗力: $\Sigma \mathrm{S}(\mathrm{kN} / \mathrm{m})$ & $8,320.45$ & $8,478.73$ & $7,948.29$ & $8,011.54$ & $6,952.62$ \\
\hline 地すべりカ: $\Sigma \mathrm{T}(\mathrm{kN} / \mathrm{m})$ & $8,638.19$ & $9,678.97$ & $10,500.96$ & $9,867.06$ & $8,055.57$ \\
\hline 粘着力: $\mathrm{c}^{\prime}\left(\mathrm{kN} / \mathrm{m}^{2}\right)$ & \multicolumn{5}{|c|}{0.000} \\
\hline 内部摩擦角: $\tan \phi^{\prime}$ & \multicolumn{5}{|c|}{$0.596707\left(\phi^{\prime}=30.2480^{\circ}\right)$} \\
\hline 二次元安全率:F2 & 1.0222 & 0.9200 & 0.7727 & 0.9153 & 0.8600 \\
\hline 三次元安全率:F3 & \multicolumn{5}{|c|}{0.8874} \\
\hline
\end{tabular}

\section{5. 超大口径鋼管杭の設計}

\section{1 設計計算式}

地すべり 鋼管杭設計要領（社団法人 地すべり対策技 術協会 発行）の抑え杭の式によより設計をおこなった。 この設計における特徽的な項目について示す。

(1)水平地盤反力係数 : $k_{\mathrm{h}}$

N值により港研式により推定した。

なお，基岩層のN值は標準貫入試験が不能であっ たため，一軸圧縮試験值より換算した。

$\mathrm{qu}=12.26 \times \mathrm{N}$

$\mathrm{N}=\mathrm{qu} / 12.26$

ここに, qu：一軸圧縮強度 $\left(\mathrm{N} / \mathrm{cm}^{2}\right)=4,108$ $\mathrm{N}: \mathrm{N}$ 值

$\therefore \mathrm{N}=4,108 / 12.26=335$

$\mathrm{k}_{\mathrm{h}}=1,961 \times \mathrm{N}=1,961 \times 335=656,935 \mathrm{kN} / \mathrm{m}^{3}$

(2)移動層の厚さ : $l \mathrm{e}$

$\mathrm{A} \sim \mathrm{E}$ 測線まの最大厚さ（A測線）19.0mを用い る。

(3)杭の根入長 $: l_{r}$

$l_{r}=(1.0 \sim 1.5) \pi / \beta$

根入部分の緑色片岩は強度が均質であることから 1.0を採用した。

\section{6. 比較と設計結果}

設計比較をおこなった杭径と杭材・肉厚は，

・掘削外径 $2,000 \mathrm{~mm}$ と $1,500 \mathrm{~mm}$ に挿入できる最大径 の $\phi 1,800 \mathrm{~mm}$ と $\phi 1,300 \mathrm{~mm}$

- SKK $-400: \mathrm{t}=9 \sim 30 \mathrm{~mm}$

$\cdot \mathrm{SKK}-490: \mathrm{t}=9 \sim 28 \mathrm{~mm}$

でおこなった。

比較設計の結果を表 -3 に示す。

杭間の地盤が破壊されることを防止して杭間中抜けを 起こさないよう杭の許容たわみ $=2 \mathrm{~cm}$ を採用したこと から，剛性が大きくたわみ難い口径の大きな杭が経済的 となる。

なお，杭の中詰めは多量の掘削土砂が発生することか ら，掘削土砂を埋め戻すこととし，杭底と杭頭部に厚さ $1 \mathrm{~m}$ のコンクリートを打設して密閉する設計とした。

\section{7. 工法採用の条件}

当工法の掘削に用いる全周回転式オールケーシング掘 削機と施工に用いるクローラクレーン（当現場では $80 \mathrm{t}$ 吊り）は大型かつ重量もあるため, 現場条件（施工ヤー ド）と資機材の搬入条件が整わないと採用できない。

\section{1 現場条件}

現場で施工に要するヤード幅は，標準で $15 \mathrm{~m} ，$ 最低で も $10 \mathrm{~m}$ を要する。(図 - 7 ) 長さは $30 \mathrm{~m}$ 程度を必要とす るが，鋼管杭施工の場合，当工法を採用するのは大規模 地すべりであり，ヤード長さが問題となることは無い。 奥大栄の場合, 排土工施工途中のステップ幅 $17 \mathrm{~m}$ の時点 
表一 3 比較設計結果

\begin{tabular}{|c|c|c|c|c|c|}
\hline 項目 & 単位 & \multicolumn{2}{|c|}{ 掘削径2,000mm } & \multicolumn{2}{|c|}{ 掘削径 $1,500 \mathrm{~mm}$} \\
\hline 仕様 & & \multicolumn{2}{|c|}{ SKK-400 $\phi 1,800 \times \mathrm{t} 30 \mathrm{~mm}$} & \multicolumn{2}{|c|}{ SKK-400 $\phi 1,300 \times \mathrm{t} 28 \mathrm{~mm}$} \\
\hline すべり面深度 & $m$ & \multicolumn{2}{|c|}{19.0 (A測線，最深) } & \multicolumn{2}{|c|}{19.0 (A測線，最深) } \\
\hline 根入長 & $\mathrm{m}$ & \multicolumn{2}{|c|}{8.17 以上 } & \multicolumn{2}{|c|}{6.85 以上 } \\
\hline 杭長 & $\mathrm{m}$ & $19.00+8.17=$ & 27.17 & $19.00+6.85=$ & 25.85 \\
\hline 施工幅 & $m$ & \multicolumn{2}{|l|}{100} & \multicolumn{2}{|l|}{100} \\
\hline 杭間隔 & $m$ & \multicolumn{2}{|l|}{$3.45 \rightarrow$} & \multicolumn{2}{|l|}{$1.02 \rightarrow$} \\
\hline 杭本数 & 本 & \multicolumn{2}{|l|}{29} & \multicolumn{2}{|l|}{100} \\
\hline 杭総延長 & $m$ & $27.17 \times 29=$ & 787.93 & $25.85 \times 100=$ & $2,585.00$ \\
\hline 掘削単価 & 円 $/ \mathrm{m}$ & & 228,831 & & 157,240 \\
\hline 総掘削費 & 千円 & & 180,303 & & 406,465 \\
\hline 杭鋼材総重量 & $t$ & $1.309 \times 787.93=$ & $1,031.4$ & $0.909 \times 2,585.00=$ & $2,349.8$ \\
\hline 鋼材単価 & 円/t & & 134,000 & & 131,000 \\
\hline 杭鋼材費 & 千円 & $1,031.4 \times 134,000=$ & 138,208 & $2349.8 \times 131,000=$ & 307,819 \\
\hline 機械運搬費: 往復 & & \multicolumn{2}{|l|}{ クローラクレーン $80 t$} & \multicolumn{2}{|l|}{ クローラクレーン60t } \\
\hline 片道距離 $180 \mathrm{~km}$ & 千円 & 掘削機 & 14,928 & 掘削機 & 12,406 \\
\hline 直接工事費 & 千円 & . & 333,439 & & 726,690 \\
\hline
\end{tabular}

※掘削単価は杭1本当たりの平均であり，土質別の比率は，碟混り土20.4\%，軟岩 I $37.7 \% ，$ 軟岩 II 41.9\%である。

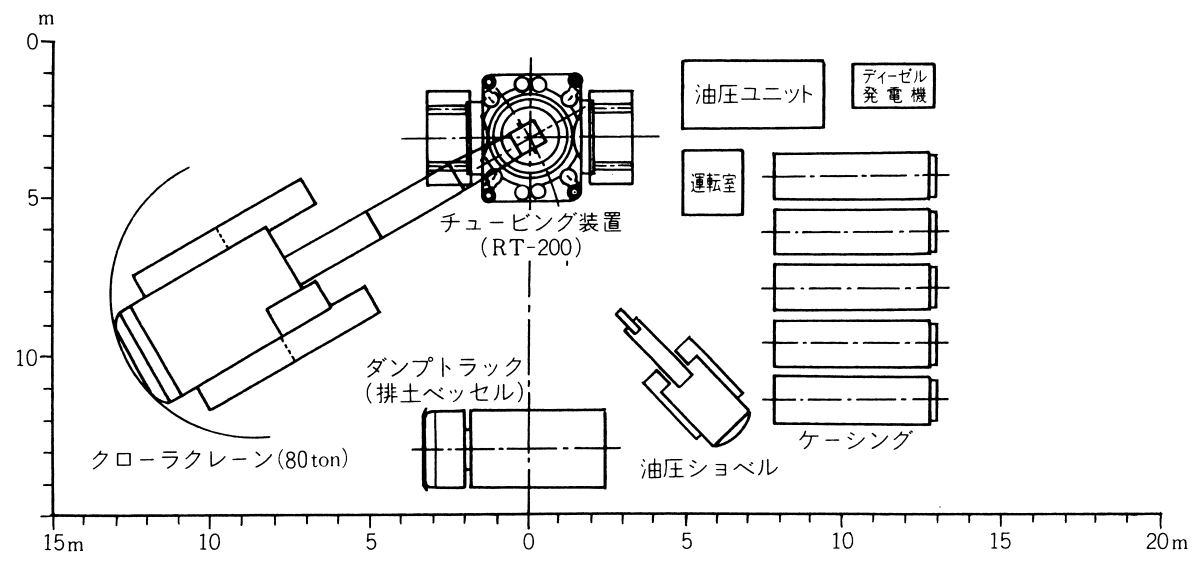

図一 7 使用資機材配置模式平面図

で施工をおこなっている。(写真－ 1 最下段のステップ が施工地である）

\section{2 資機材の搬入搬出条件}

使用する資機材の内，特に大型で重量のあるものは掘 削機械とクローラクレーンである。

奥大栄で使用した $\phi 2,000 \mathrm{~mm}$ オールケーシング掘削機 と $80 \mathrm{t}$ 吊りクローラクレーンの重量は，それぞれ， $35.7 \mathrm{t}$ と74.6tであり，20tを超えるため分解運搬が必要となる。 通常の運搬ではセミトレーラーを使用するが，山間部 の県道では，まず通行不可な場合が多い。奥大栄では最 小幅員 $3.0 \mathrm{~m}$ の作業道を開設したが，県道通行の重量制 限より $12 \mathrm{t}$ トラックによる運搬が可能な分解をおこなっ て搬入・搬出をおこなった。

$\phi 2,000 \mathrm{~mm}$ オールケーシング掘削機と $80 \mathrm{t}$ 吊りクロー ラクレーンの通常分解運搬と，12t分解運搬の経費差は 運搬距離 $180 \mathrm{~km}$ で片道当たり 262 万円である。12t車の通 行が可能であれば比較検討工法に採用できる。

·通常分解 $180 \mathrm{~km}$ 片道運搬 $=7,464$ 千円

- $12 \mathrm{t}$ 分解 $180 \mathrm{~km}$ 片道運搬 $=10,080$ 千円（見積もり）

\section{8. 超大口径鋼管杭の施工}

\section{1 主要機械・資材 ${ }^{5)}$}

施工に用いる主要機械および資材を示す。 主要機械

(1)オールケーシング掘削機：RT-200：1台

(2)80t吊りクローラクレーン：KH300：1台

(3)バックホウ : $0.45 \mathrm{~m}^{3}: 1$ 台

主要資材

(1)発動発電機：60KVA：1 台

(2)ケーシング保護キャップ : $\phi 2,000 \mathrm{~mm}$ 用 : 1

(2)特殊ケーシングチューブ : $\phi 2,000 \mathrm{~mm}$ 用

: 各 $6 \sim 1 \mathrm{~m} 1$ 式（最長掘削長 $+3 \mathrm{~m}$ )

(3)特殊ファーストチューブ : $\phi 2,000 \mathrm{~mm}$ 用：2 本

（特殊ビット付き，予備 1 )

(4)ハンマーグラブ : $\phi 2,000 \mathrm{~mm}$ 用 : 1

(5)ハンマークラウン： ：1

(6)チゼル：4t：1（砕岩用）

(7)ミニクリートポンプ: $4 \sim 7 \mathrm{~m}^{3} / \mathrm{h}: 1$

(モルタル注入用)

8)水中ポンプ：3 インチ, 2 インチ：各 1

(9)水槽: $3 \mathrm{~m}^{3}: 1$ 


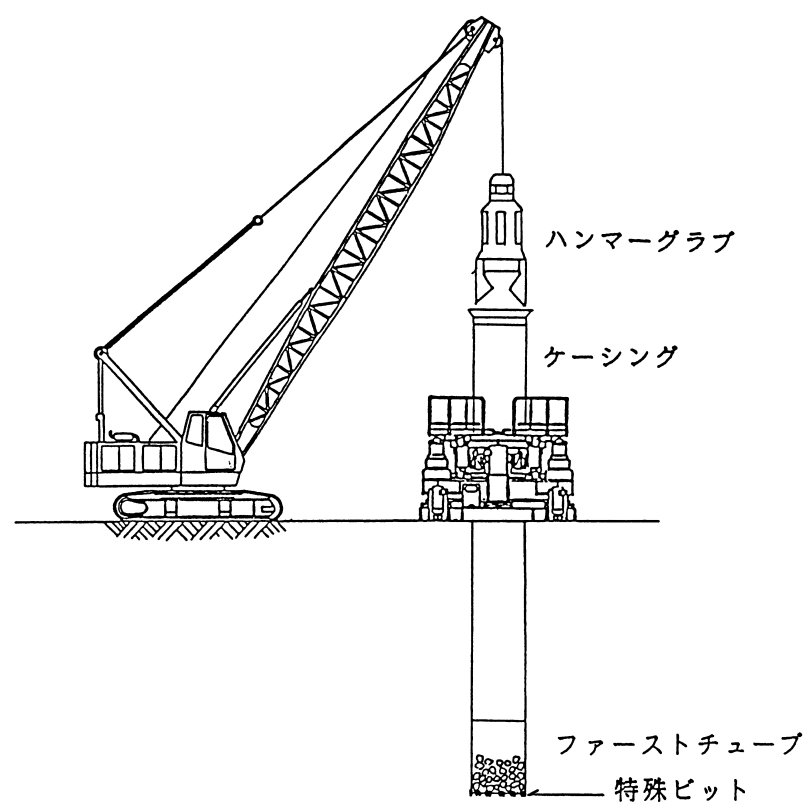

図－8 オールケーシング掘削機 掘削姿勢

(10)ハイウォシャー：1（洗浄用）

(11)敷鉄板 : $5^{\prime} \times 10^{\prime}: 10$ 枚

(12)全自動溶接機：W4410A

(13)ガス器具一式

(14)その他雑機材： 1 式

\section{2 施工方法}

施工手順の概略を記す。

(1)掘削機の据え付け

クローラクレーンにて施工位置に掘削機を設置し，反 カウェイトをセットする。

(2)ケーシングセット・鉛直確認

掘削機を設置した後，クレーンにて 1 本目のケーシン グをセットし，2 方向よりトランシットで鉛直性を確認 する。鉛直性の調整は掘削機の水平ジャッキによりおこ なう。

(3)ハンマーグラブセット

1 本目のケーシングセットが完了した後, クレーンに ハンマーグラブをセットし掘削を開始する。

(4)掘削・排土

ケーシングを徐々に回転し，鉛直を確認しながらケー シングを下げる。この時再度鉛直性を確認する。1 本目 のケーシングチューブの押し込みが完了した後，第 2 ケーシングチューブをクレーンで吊达みセットし，ロッ クピンで固定する。ケーシングを全周回転させ押し込み, ケーシング内の掘削土砂・岩塊をハンマーグラブにて排 土する。排土した土砂・岩塊は水切りした後鋼管中詰に 用いる。岩塊が大きく排土できない場合はケーシング内 にチゼルを落下させて小割りし，排土する。

(5)ケーシングの継ぎ足し

掘削・排土の進行に従い随時ケーシングを継ぎ足す。 6)設計深度到達

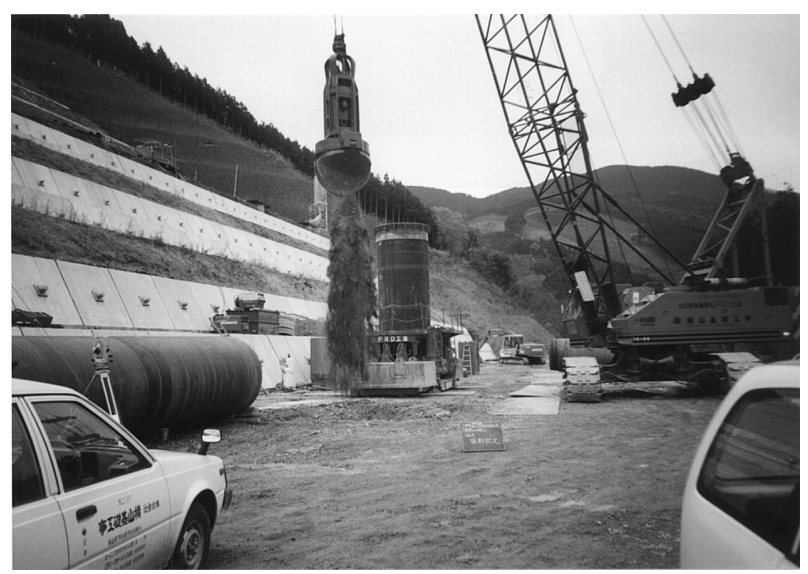

写真一 2 施工状況

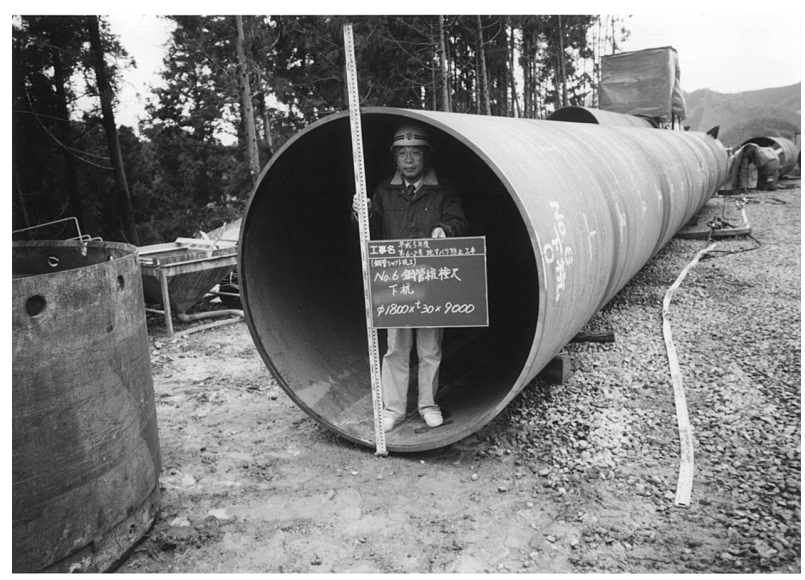

写真一 3 鋼管 $\phi 1,800 \times \mathrm{t} 30, \mathrm{~L}=9.00 \mathrm{~m}$

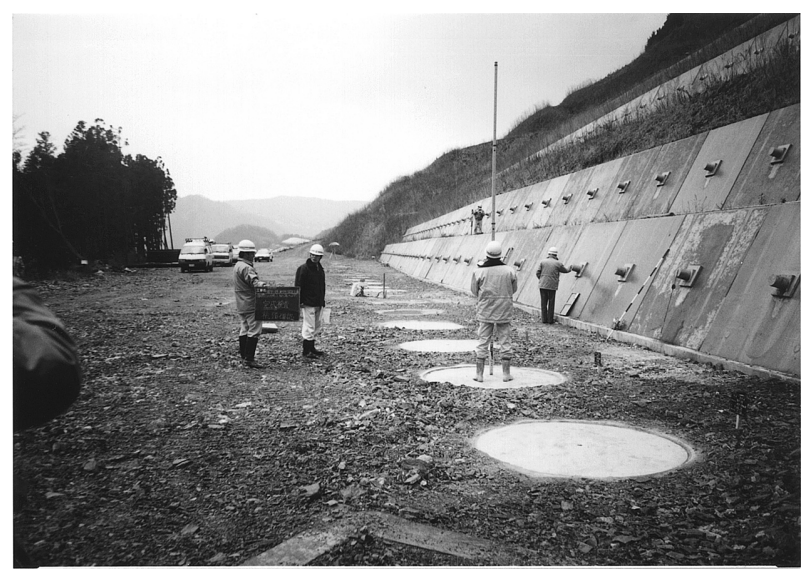

写真 -4 超大口径鋼管杭工完成

設計深度まで掘削するときは，掘り過ぎないよう注意 して掘削する。鋼管杭全重量は最大 $35.998 t$ あ，天端 標高を調整することは容易ではない。

(7)検尺

スライム処理が完了した後，検尺テープにより所定の 深さまで掘削がおこなわれていることを確認する。

8)鋼管の建て込み・溶接

鋼管をケーシング内に建て込み，吊り金具をケーシン 
グ天端に掛け下杭を仮置きする。上杭を建て込み全自動 溶接機をセットして溶接する。溶接等の作業が掘削機の 上部でおこなえる様，ケーシングの全長は掘削長 +2.8 mないし $3.3 \mathrm{~m}$ となる様にケーシングを組み合わせた。

溶接に際しては防風設備を設けて溶接をおこなった。 (9)中詰工および外周モルタル打設

鋼管の建込みが完了し，天端高さを確認した後，杭底 に $1 \mathrm{~m}$ コンクリートを打設する。岩盤部分のケーシング を抜き上げた後，この量に見合うモルタルをサニーホー スとミニクリートポンプにて打設する。その後ケーシン グを 1 本ずつ抜き上げモルタル打設を繰り返す。

水切りの完了した掘削土砂を鋼管内に天端より $1 \mathrm{~m}$ 下 まで投入し，最後に $1 \mathrm{~m}$ のコンクリートを打設する。 (10)次の杭への移設

奥大栄では掘削機の大きさ $4.16 \times 6.72 \mathrm{~m}$ に対して杭間 隔が $3.40 \mathrm{~m}$ と狭いため 1 本飛ばしに施工をおこなってい る。

\section{9. おわりに}

超大口径鋼管杭工は，使用機械の運搬がネックである が，奥大栄地区の事例では，12t車分解運搬と通常の分 解運搬の差は運搬距離 $180 \mathrm{~km}$ で262万円/片道しかなく， 大規模地すべりの抑止工では検討に值する工法であると
言える。

また，掘削の概算単価を平成 5 年当時の愛媛県単価で @ 229 千円 $/ \mathrm{m}^{6}$ と示した。平成17年度では労務単価が平 成 5 年度の $80 \%$ 程度，機械損料で $85 \%$ 程度となっている ので@190千円/m程度と考えて良いであろう。

本ケースは，急傾斜地に発生した大規模地すべりに採 用した抑え杭という特殊なケースであるが，これに対比 できるシャフト杭工に比べて，施工効率・安全性・静肃 性および経済性においても優れた工法であった。

本報告が大規模地すべりの抑止工を検討する場合の参 考になれば幸いである。

\section{参考文献}

1) 申 潤植 (1989)：地すべり工学 理論と実践, 山海堂 p. 842

2) 申 潤植 (1989)：地すべり工学 理論と実践, 山海堂 p. 649

3 ) 申 潤植 (2001)：新版地すべり工学 最新のトピックス, 山 海堂 p. 113 , p. 136

4 ）地すべり鋼管杭設計施工要領検討委員会（1990）：地すべり 鋼管杭設計要領, 社)地すべり対策技術協会 p. 64

5 ）(社)地すべり対策技術協会（1996）：地すべり対策技術設計実 施要領 p. 291

6 ）社)日本建設機械化協会 (平成 5 年度版)：大口径岩盤削孔工 法の積算 p. 59

（原稿受付 2005 年 11 月 30 日，原稿受理2006年 6 月 12 日） 